\title{
Electrospinning of Polymer-free Nanofibers from Cyclodextrin Inclusion Complexes
}

\author{
Asli Celebioglu and Tamer Uyar* \\ UNAM-Institute of Materials Science \& Nanotechnology, Bilkent University, Ankara 06800, Turkey
}

ABSTRACT: The electrospinning of polymer-free nanofibers from highly concentrated $(160 \%, \mathrm{w} / \mathrm{v})$ aqueous solutions of hydroxypropyl- $\beta$-cyclodextrin $(\mathrm{HP} \beta \mathrm{CD})$ and its inclusion complexes with triclosan ( $\mathrm{HP} \beta \mathrm{CD} /$ triclosan-IC) was achieved successfully. The dynamic light scattering (DLS) and rheology measurements indicated that the presence of considerable $\mathrm{HP} \beta \mathrm{CD}$ aggregates and the high solution viscosity were the key factors in obtaining electrospun $\mathrm{HP} \beta C D$ and $\mathrm{HP} \beta C D$ / triclosan-IC nanofibers without the use of any polymeric carrier. The $\mathrm{HP} \beta \mathrm{CD}$ and $\mathrm{HP} \beta \mathrm{CD} /$ triclosan-IC solutions containing

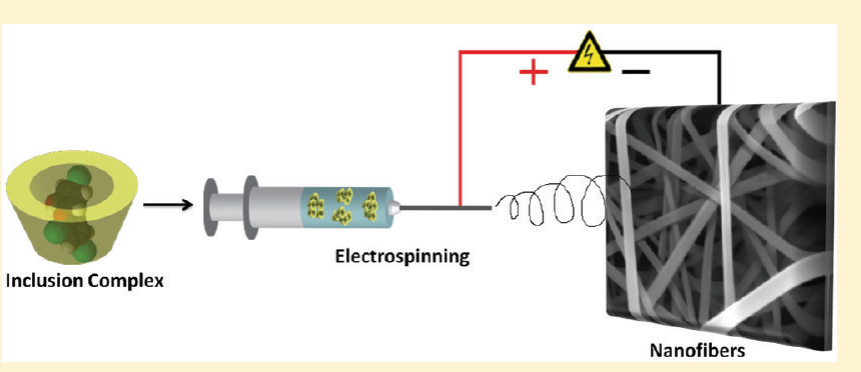
$20 \%(\mathrm{w} / \mathrm{w})$ urea yielded no fibers but only beads and splashes because of the depression of the self-aggregation of the HP $\beta \mathrm{CD}$. The inclusion complexation of triclosan with $\mathrm{HP} \beta \mathrm{CD}$ was studied by isothermal titration calorimetry (ITC) and turbidity measurements. The characteristics of the $\mathrm{HP} \beta \mathrm{CD}$ and $\mathrm{HP} \beta \mathrm{CD}$ /triclosan-IC nanofibers were investigated by Fourier transform infrared spectroscopy (FTIR), thermogravimetric analysis (TGA), X-ray diffraction (XRD), and differential scanning calorimetry (DSC). It was found that the electrospinning of $\mathrm{HP} \beta \mathrm{CD} /$ triclosan-IC solution having a 1:1 molar ratio was optimal for obtaining nanofibers without any uncomplexed guest molecules.

\section{INTRODUCTION}

Electrospinning has attracted a great amount of attention in the past decade because this cost-effective and versatile technique facilitates the production of functional nanofibers from various polymers, polymer blends, and polymer composites. ${ }^{1-6}$ In principle, high-molecular-weight polymers and high polymer concentrations are required for the electrospinning of fibers because polymer chain entanglements and overlapping are very crucial to fiber formation during the electrospinning process. ${ }^{7,8}$ Nevertheless, recently it has been demonstrated that microfibers of lowmolar-mass gemini surfactant ${ }^{9}$ and phospholipid ${ }^{10}$ were electrospun because these molecules can form cylindrical micelles that can overlap and entangle in a fashion similar to polymers in their concentrated solutions. Very recently, we have also achieved the electrospinning of methyl- $\beta$-cyclodextrin $(\mathrm{M} \beta \mathrm{CD})$ nanofibers without using a polymeric carrier matrix. ${ }^{11}$ Cyclodextrins (CDs) are capable of self-assembly and form aggregates via intermolecular interactions such as hydrogen bonding in their solutions. ${ }^{12-14}$ The success of the electrospinning of nanofibers from such small molecules is due to the presence of considerable aggregates and reasonable intermolecular interactions between the CD molecules in their concentrated solutions.

CDs are cyclic oligosaccharides having a toroid-shaped molecular structure (Figure 1) that can form noncovalent host-guest inclusion complexes with a variety of molecules including drugs, antibacterials, food additives, textile auxiliaries, and so forth. ${ }^{15,16}$ Because the stability, solubility, reactivity, and controlled release of guest molecules can be enhanced by complexation with $\mathrm{CD}$, the cyclodextrin inclusion complexes (CD-IC) are used in various application areas such as pharmaceuticals, functional foods, textiles, sustained/controlled delivery systems, sensors, and many other advanced functional systems. ${ }^{15-19}$

Previously, we have produced electrospun functional polymeric nanofibers containing CDs, ${ }^{20-22} \mathrm{CD}-\mathrm{ICs},{ }^{23,24}$ and $\mathrm{CD}$ pseudopolyrotaxanes. ${ }^{25}$ Here, we report on the very first studies on the electrospinning of CD-IC by itself without using a carrier polymer matrix. In this study, we achieved the electrospinning of polymer-free nanofibers from hydroxypropyl- $\beta$-cyclodextrin $(\mathrm{HP} \beta \mathrm{CD})$ and its inclusion complexes with triclosan $(\mathrm{HP} \beta \mathrm{CD} /$ triclosan-IC). We anticipated that the electrospinning of nanofibers from CD-ICs would be particularly attractive because of the exclusive properties obtained by combining the very large surface area of nanofibers/nanowebs with specific functionality of the CD-ICs.

\section{EXPERIMENTAL SECTION}

Materials. Triclosan (>\%97 (HPLC), Sigma, Germany) and urea (>\%99.5, Merck, Germany) were purchased commercially. The water used was from a Millipore Milli-Q ultrapure water system. The HP $\beta$ CD was obtained from Wacker Chemie AG (Germany). The materials were used without any purification.

Preparation of HP $\beta C D$ and HP $\beta C D / T$ riclosan-IC Solutions. The formation of $\mathrm{HP} \beta \mathrm{CD}$ /triclosan-IC was achieved in aqueous solution by using a 1:1 molar ratio of $\mathrm{HP} \beta \mathrm{CD} /$ triclosan. Additionally, we

Received: December 19, 2010

Revised: March 18, 2011

Published: April 22, 2011 

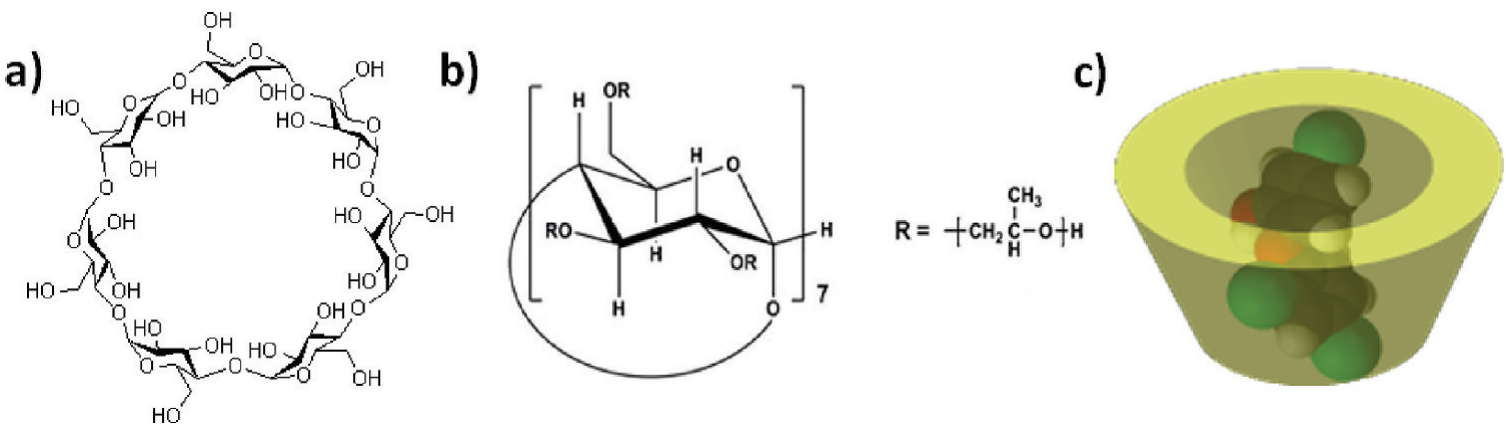

Figure 1. Chemical structure of (a) $\beta$-CD and (b) $\mathrm{HP} \beta \mathrm{CD}$. (c) Schematic representation of the cyclodextrin/triclosan inclusion complex.

have also prepared $\mathrm{HP} \beta \mathrm{CD} /$ triclosan-IC containing a higher amount of a guest molecule: $\mathrm{HP} \beta \mathrm{CD} /$ triclosan having 1:1.3 mol ratio. For $\mathrm{HP} \beta \mathrm{CD} /$ triclosan-IC, first triclosan was put in water and stirred at $40^{\circ} \mathrm{C}$ for $0.5 \mathrm{~h}$. Because triclosan is not water-soluble, we obtained a dispersion. Then, $\operatorname{HP} \beta C D(160 \%, w / v)$ was added to the triclosan solution, and the solution became clear after stirring for $0.5 \mathrm{~h}$ at $40{ }^{\circ} \mathrm{C}$ because of the dissolution of triclosan by forming an inclusion complex with $\mathrm{HP} \beta \mathrm{CD}$. As the solution was cooled down and stirred overnight at room temperature, a white, highly turbid $\mathrm{HP} \beta \mathrm{CD} /$ triclosan-IC solution was obtained. However, a homogeneous, clear aqueous solution of $\mathrm{HP} \beta \mathrm{CD}$ was prepared by dissolving $\mathrm{HP} \beta \mathrm{CD}(160 \%, \mathrm{w} / \mathrm{v})$ in water by stirring for $1 \mathrm{~h}$ at $50{ }^{\circ} \mathrm{C}$; thereafter, it was cooled to room temperature before electrospinning. The clear $\mathrm{HP} \beta \mathrm{CD}$ solution and the turbid $\mathrm{HP} \beta \mathrm{CD} /$ triclosan-IC solutions having 1:1 and 1:1.3 molar ratios were electrospun. For comparison, a physical mixture of $\mathrm{HP} \beta \mathrm{CD} /$ triclosan was prepared in the solid state by grinding $\mathrm{HP} \beta \mathrm{CD}$ nanofibers and triclosan in an agar mortar for 15 min by using an identical molar ratio $(1: 1)$.

Electrospinning. The clear solution of $\mathrm{HP} \beta \mathrm{CD}$ and the turbid solutions of $\mathrm{HP} \beta \mathrm{CD} /$ triclosan-IC were placed in a $1 \mathrm{~mL}$ syringe fitted with a metallic needle of $0.45 \mathrm{~mm}$ inner diameter. The syringe was fixed horizontally on the syringe pump (model SP 101IZ, WPI, USA). The electrode of the high-voltage power supply (Matsusada Precision, AU Series, Japan) was clamped to the metal needle tip, and the cylindrical aluminum collector was grounded. The feed rate of solutions was $0.5 \mathrm{~mL} / \mathrm{h}$, the applied voltage was $15 \mathrm{kV}$, and the tip-to-collector distance was kept at $10 \mathrm{~cm}$. Electrospun nanofibers were deposited on a grounded stationary cylindrical metal collector covered with a piece of aluminum foil. The electrospinning apparatus was enclosed in a Plexiglas box, and electrospinning was carried out at $24{ }^{\circ} \mathrm{C}$ at $45 \%$ relative humidity. The collected nanofibers were dried at room temperature under the fume hood overnight and stored several days before their analyses.

Measurements and Characterization. A Nano-ZS Zetasizer dynamic light scattering (DLS) system (Malvern Instruments, U.K.) was used to measure the particle size of the aggregates in $\mathrm{HP} \beta \mathrm{CD}$ solutions.

A rheometer (Anton Paar Physica MCR 301, Austria) equipped with a cone/plate accessory (spindle type CP40-2) was used to measure the rheological behavior of the $\mathrm{HP} \beta \mathrm{CD}$ and $\mathrm{HP} \beta \mathrm{CD} /$ triclosan-IC solutions in the range of 0.1 to $100 \mathrm{~Pa}$ with shear stress at $22^{\circ} \mathrm{C}$.

The isothermal titration experiment was performed by using isothermal titration calorimetry (ITC) (ITC200 Microcalorimeter, France), and the data were analyzed with Origin software. Water was used as the solvent system for both $\mathrm{HP} \beta \mathrm{CD}$ and triclosan. A $0.025 \mathrm{mM}$ triclosan dispersion was prepared and sonicated for $15 \mathrm{~min}$. While the reaction cell was filled with $200 \mu \mathrm{L}$ of triclosan solution, the syringe was filled with $40 \mu \mathrm{L}$ of the $\mathrm{HP} \beta \mathrm{CD}$ solution $(0.25 \mathrm{mM})$. The experiment was carried out at $25^{\circ} \mathrm{C}$ by titrating $(1 \mu \mathrm{L} /$ injection, 40 injections total $)$ the $\mathrm{HP} \beta \mathrm{CD}$ solution into the triclosan solution. The reference cell was charged with $150 \mu \mathrm{L}$ of deionized water, and the system was strirred at $500 \mathrm{rpm}$ during the titration. To attain thermal equilibrium between each titration, $200 \mathrm{~s}$ time intervals were applied.

A UV-vis-NIR spectrophotometer (Varian Cary 5000, USA) was used in the wavelength range of $400-800 \mathrm{~nm}$ to observe the absorbance differentiation as the $\mathrm{HP} \beta \mathrm{CD} /$ triclosan-IC solution became turbid in the progressing time interval. For this, the $\mathrm{HP} \beta \mathrm{CD} /$ triclosan-IC $(1: 1)$ solution was prepared and the absorption measurements were taken after $1,3,6,9,12$, and $15 \mathrm{~h}$.

The analyses of the collected nanofibers were carried out after several days of their production. A scanning electron microscope (SEM) (FEI-Quanta 200 FEG, Netherlands) was used for the morphological investigation of the electrospun nanofibers. Samples were sputtered with $7 \mathrm{~nm} \mathrm{Au} / \mathrm{Pd}$ prior to SEM imaging. The average fiber diameter (AFD) was determined from the SEM images, and around 100 fibers were analyzed.

The X-ray diffraction (XRD) (PANalytical X'Pert powder diffractometer, Netherlands) data of the $\mathrm{HP} \beta \mathrm{CD}, \mathrm{HP} \beta \mathrm{CD} /$ triclosan-IC nanofibers and the physical mixture of $\mathrm{HP} \beta \mathrm{CD}$ /triclosan were recorded by using $\mathrm{Cu} \mathrm{K} \alpha$ radiation in a range of $2 \theta=5-30^{\circ}$.

Differential scanning calorimetry (DSC) (TA Q2000, USA) and thermogravimetric analysis (TGA) (TA Q500, USA) were used for the investigation of the thermal properties of the samples. DSC analyses were carried out under $\mathrm{N}_{2}$; initially, samples were equilibrated at $-90^{\circ} \mathrm{C}$ and then heated to $300^{\circ} \mathrm{C}$ at a heating rate of $10^{\circ} \mathrm{C} / \mathrm{min}$. The TGA of the samples was carried out from 25 to $500{ }^{\circ} \mathrm{C}$ at a $20^{\circ} \mathrm{C} / \mathrm{min}$ heating rate, and $\mathrm{N}_{2}$ was used as a purge gas.

The infrared spectra of the samples were obtained by using a Fourier transform infrared spectrometer (FTIR) (Bruker-VERTEX 70, Germany). The samples were mixed with potassium bromide $(\mathrm{KBr})$ and pressed as pellets. The scans ( 64 scans) were recorded between 4000 and $400 \mathrm{~cm}^{-1}$ at a resolution of $4 \mathrm{~cm}^{-1}$.

\section{RESULTS AND DISCUSSION}

Electrospinning of HP $\beta C D$ Nanofibers. $\beta$-CD has very limited water solubility, ${ }^{26}$ yet the chemical modification of $\beta$-CD by random substitution of the hydroxyl groups of $\mathrm{CD}$ with hydroxypropyl groups resulted in amorphous $\mathrm{HP} \beta \mathrm{CD}$ having much higher aqueous solubility compared to that of native $\beta-\mathrm{CD} .{ }^{29}$ Here, we prepared clear aqueous solutions of $\mathrm{HP} \beta \mathrm{CD}$ having very high concentrations $(100,120,140$, and $160 \%, w / v)$ for the electrospinning of $\mathrm{HP} \beta \mathrm{CD}$ nanofibers without using a polymeric carrier. At lower $\operatorname{HP} \beta C D$ concentrations $(100-140 \%$, w/v), beads and beaded nanofibers were obtained. However, at $160 \%(\mathrm{w} / \mathrm{v})$ concentration, bead-free uniform $\mathrm{HP} \beta \mathrm{CD}$ nanofibers (Figure $2 \mathrm{a}$ ) were produced with fiber diameters in the range of 200-1600 nm having an average fiber diameter of $745 \pm 370 \mathrm{~nm}$ (Figure $2 \mathrm{~b}$ and Table 1 ).

We have investigated the characteristics of the concentrated $\mathrm{HP} \beta \mathrm{CD}$ solutions by DLS and rheology measurements in order 

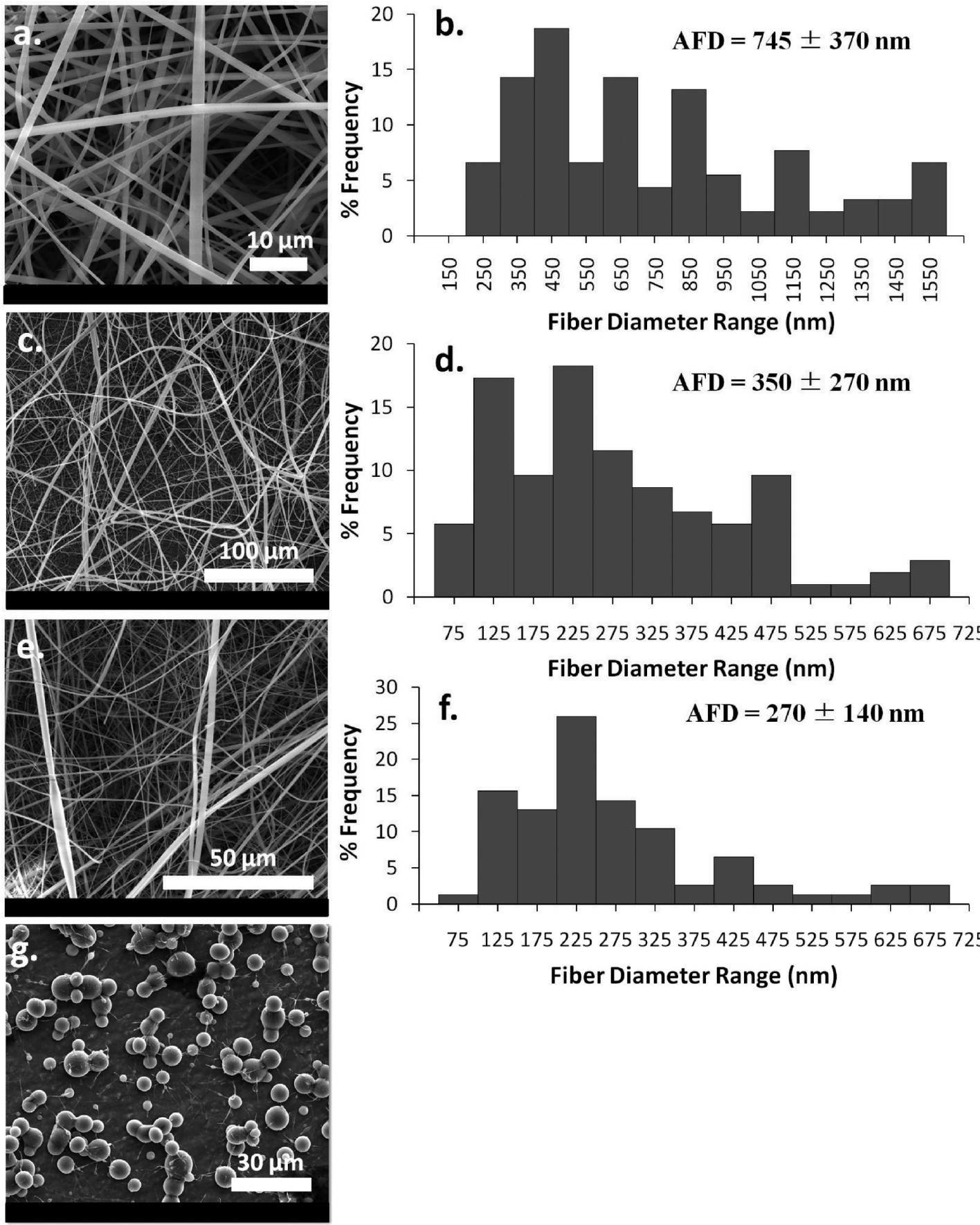

75125175225275325375425475525575625675725

Fiber Diameter Range (nm)

Figure 2. Representative SEM image of (a) HP $\beta$ CD nanofibers obtained from a $160 \%$ (w/v) HP $\beta$ CD solution and (b) the fiber diameter distribution. SEM images of $\mathrm{HP} \beta \mathrm{CD}$ nanofibers containing (c) 5 and (e) $10 \%(\mathrm{w} / \mathrm{w})$ urea and $(\mathrm{d}, \mathrm{f})$ their fiber diameter distributions, respectively. (g) SEM image of bead structures obtained from $160 \%(\mathrm{w} / \mathrm{v}) \mathrm{HP} \beta \mathrm{CD}$ containing $20 \%(\mathrm{w} / \mathrm{w})$ urea.

to understand the electrospinnability of $\mathrm{HP} \beta \mathrm{CD}$ by itself. Studies have shown that CDs are capable of self-assembly and form aggregates via intermolecular interactions in their concentrated solutions. ${ }^{12-14}$ Here, the DLS measurements revealed the presence of self-aggregated $\mathrm{HP} \beta \mathrm{CD}$ molecules in their concentrated solutions (Figure $3 \mathrm{a}$ and Table 2 ). The size of the aggregates was measured to be around $6.5 \mathrm{~nm}$ with a polydispersity index (PDI) of 0.26 for $100 \%(\mathrm{w} / \mathrm{v}) \mathrm{HP} \beta \mathrm{CD}$ solution. At 120 and $140 \%$ $(\mathrm{w} / \mathrm{v}) \mathrm{HP} \beta \mathrm{CD}$ solutions, the size of the aggregates increased to $7.0 \mathrm{~nm}(\mathrm{PDI}=0.32)$ and $8.0 \mathrm{~nm}(\mathrm{PDI}=0.35)$, respectively. The size of the aggregates reached $9.2 \mathrm{~nm}(\mathrm{PDI}=0.40)$ for a $160 \%$ $(\mathrm{w} / \mathrm{v}) \mathrm{HP} \beta \mathrm{CD}$ solution. The DLS measurements clearly showed that the size of the $\mathrm{HP} \beta \mathrm{CD}$ aggregates was increased and the particle size distribution became broader as the concentration of the $\operatorname{HP} \beta C D$ solution increased from 100 to $160 \%$ (w/v).

Rheological measurements for $\mathrm{HP} \beta \mathrm{CD}$ and $\mathrm{HP} \beta \mathrm{CD} /$ triclosan-IC solutions were also performed. $\mathrm{HP} \beta \mathrm{CD}$ and $\mathrm{HP} \beta \mathrm{CD} /$ triclosan-IC solutions showed Newtonian behavior, as seen from the rheology data (Figure 4). A significant increase in the viscosity of the $\mathrm{HP} \beta \mathrm{CD}$ solutions was recorded as the concentration of 
Table 1. Morphological Findings of the Resulting Electrospun Nanofibers Obtained from HP $\beta \mathrm{CD}$ and $\mathrm{HP} \beta \mathrm{CD} / \mathrm{Triclosan}-\mathrm{IC}$ Solutions

\begin{tabular}{lclc}
\multicolumn{1}{c}{ solution } & urea $(\%, \mathrm{w} / \mathrm{w})$ & fiber morphology & fiber diameter range (nm) \\
$\mathrm{HP} \beta \mathrm{CD}$ & & bead-free nanofibers & $200-1600$ \\
$\mathrm{HP} \beta \mathrm{CD}$ & 5 & bead-free nanofibers & $50-700$ \\
$\mathrm{HP} \beta \mathrm{CD}$ & 10 & bead-free nanofibers & $50-700$ \\
$\mathrm{HP} \beta \mathrm{CD}$ & 20 & no fiber formation & $200-900$ \\
$\mathrm{HP} \beta \mathrm{CD} /$ triclosan-IC $(1: 1)$ & & bead-free nanofibers & $530 \pm 270$ \\
$\mathrm{HP} \beta \mathrm{CD} /$ triclosan-IC $(1: 1.3)$ & & bead-free nanofibers & $50-900$ \\
$\mathrm{HP} \beta \mathrm{CD} /$ triclosan-IC $(1: 1)$ & 20 & no fiber formation & $570 \pm 130$ \\
\hline
\end{tabular}
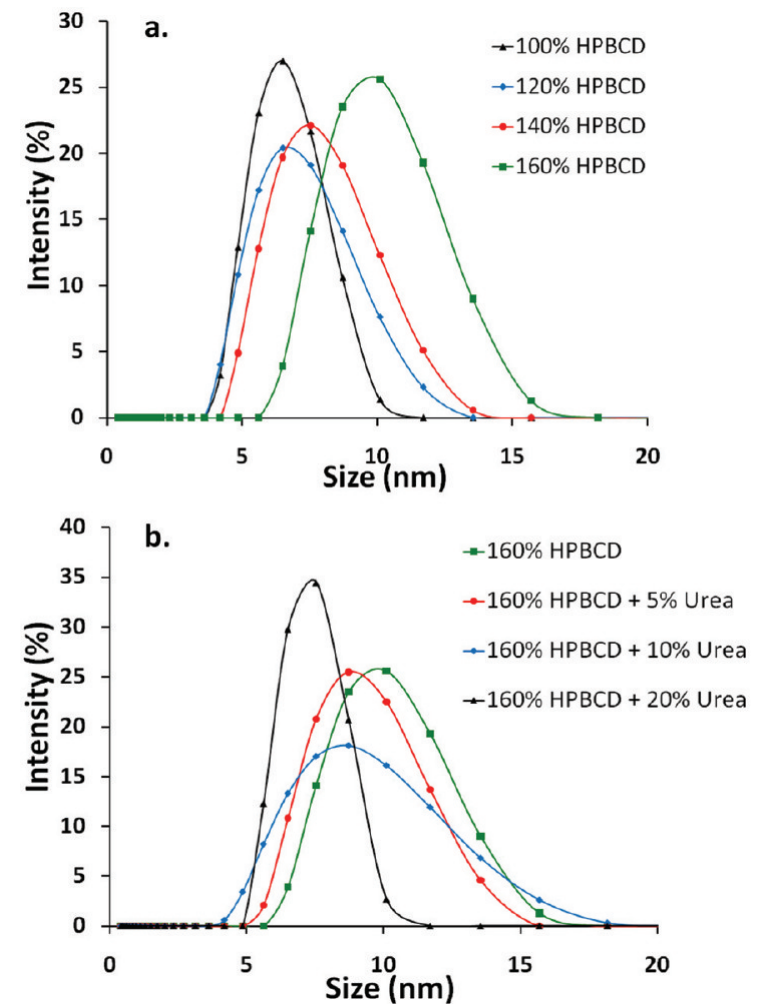

Figure 3. Size distribution of $\mathrm{HP} \beta \mathrm{CD}$ aggregates for (a) $100,120,140$, and $160 \%(\mathrm{w} / \mathrm{v}) \mathrm{HP} \beta \mathrm{CD}$ concentrations and for (b) $160 \%(\mathrm{w} / \mathrm{v})$ $\mathrm{HP} \beta \mathrm{CD}$ concentration including 5, 10, and $20 \%(\mathrm{w} / \mathrm{w})$ urea.

$\mathrm{HP} \beta \mathrm{CD}$ increased from 100 to $160 \%(\mathrm{w} / \mathrm{v})$. The DLS and rheology data are in good agreement with each other, and higher solution viscosity was possibly due to the higher number of $\mathrm{HP} \beta \mathrm{CD}$ aggregates and their growing sizes in their concentrated solutions.

At lower $\mathrm{HP} \beta \mathrm{CD}$ concentrations $(100-140 \%, \mathrm{w} / \mathrm{v})$, the electrospinning of uniform $\mathrm{HP} \beta \mathrm{CD}$ nanofibers was not achieved possibly because of the insufficient number of $\mathrm{HP} \beta \mathrm{CD}$ aggregates and their smaller particle size that resulted in the destabilization of the electrified jet during electrospinning. This behavior is typically observed for polymer solutions having lower concentrations and electrospinning yield beads and/or beaded nanofibers because of the lack of sufficient polymer chain entanglements and overlapping. ${ }^{1,8,28}$ At $160 \%(\mathrm{w} / \mathrm{v})$ $\mathrm{HP} \beta \mathrm{CD}$ concentration, SEM findings suggested that full stretching of the electrified jet was achieved because of the high solution viscosity and the presence of a considerable number of $\mathrm{HP} \beta \mathrm{CD}$ aggregates; therefore, bead-free $\mathrm{HP} \beta \mathrm{CD}$ nanofibers were obtained.
Table 2. DLS Measurements of $\mathrm{HP} \beta \mathrm{CD}$ Solutions at $25^{\circ} \mathrm{C}$ (Equilibrium at $25^{\circ} \mathrm{C}$ for 2 Minutes Prior to Measurement) Summarizing the Average Diameter $(\mathrm{nm})$ and Polydispersity Index (PDI) of HP $\beta$ CD Aggregates

\begin{tabular}{lcc}
\multicolumn{1}{c}{ sample } & intensity-average diameter $(d, \mathrm{~nm})$ & PDI \\
$100 \% \mathrm{HP} \beta \mathrm{CD}$ & 6.5 & 0.26 \\
$120 \% \mathrm{HP} \beta \mathrm{CD}$ & 7.0 & 0.32 \\
$140 \% \mathrm{HP} \beta \mathrm{CD}$ & 8.0 & 0.35 \\
$160 \% \mathrm{HP} \beta \mathrm{CD}$ & 9.2 & 0.40 \\
$160 \% \mathrm{HP} \beta \mathrm{CD}+5 \%$ urea & 9.1 & 0.36 \\
$160 \% \mathrm{HP} \beta \mathrm{CD}+10 \%$ urea & 9.0 & 0.48 \\
$160 \% \mathrm{HP} \beta \mathrm{CD}+20 \%$ urea & 8.1 & 0.28 \\
\hline
\end{tabular}
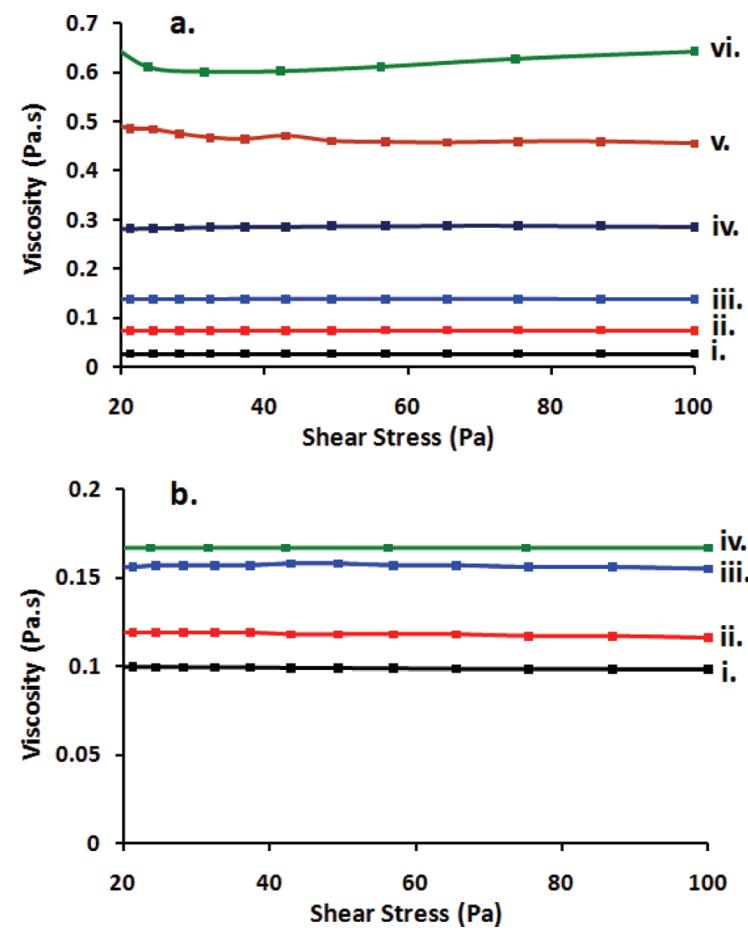

Figure 4. Steady shear viscosity of (a, i) 100 , (ii) 120 , (iii) 140 , and (iv) $160 \%$ (w/v) HP $\beta$ CD solution, (v) $\mathrm{HP} \beta \mathrm{CD} /$ triclosan-IC (1:1.3), and (vi) $\mathrm{HP} \beta \mathrm{CD} /$ triclosan-IC (1:1) solutions. (b) $160 \%$ (w/v) $\mathrm{HP} \beta \mathrm{CD}$ solution containing (i) 20 , (ii) 10 , and (iii) $5 \%(\mathrm{w} / \mathrm{w}$ ) urea and (iv) a $\mathrm{HP} \beta \mathrm{CD} /$ triclosan-IC $(1: 1)$ solution containing $20 \%(\mathrm{w} / \mathrm{w})$ urea.

It is known that the addition of urea breaks the hydrogen bonds between $\mathrm{CD}$ molecules and therefore causes a notable 
depression of the self-association of the $\mathrm{CD}$ molecules in water. $^{29,30}$ Here, we added urea $(5,10$, and $20 \%(\mathrm{w} / \mathrm{w})$ with respect to $\mathrm{HP} \beta \mathrm{CD}$ ) to the $160 \%$ (w/v) $\mathrm{HP} \beta \mathrm{CD}$ aqueous solution. We observed that the size of the aggregates got smaller (Figure $3 \mathrm{~b}$ and Table 2 ) and the viscosity of the $\mathrm{HP} \beta \mathrm{CD}$ solution decreased as the urea content increased from 5 to $20 \%$ $(\mathrm{w} / \mathrm{w})$ (Figure $4 \mathrm{~b})$. The electrospinning of a $160 \%(\mathrm{w} / \mathrm{v})$ $\mathrm{HP} \beta \mathrm{CD}$ aqueous solution containing 5 and $10 \%(\mathrm{w} / \mathrm{w})$ urea yielded thinner nanofibers (Figure $2 c, e$ ) in the range of $50-700 \mathrm{~nm}$ having average fiber diameters of $350 \pm 270$ and $270 \pm 140 \mathrm{~nm}$, respectively (Figure 2d,f). The urea (5 and 10\%, $\mathrm{w} / \mathrm{w}$ )-containing $\mathrm{HP} \beta \mathrm{CD}$ solutions yielded thinner fibers possibly because of the low viscosity of the solutions; therefore, the jet was subjected to more stretching during electrospinning. This behavior is very typical for the electrospinning of polymer solutions having a low viscosity which resulted in thinner fibers when electrospun. ${ }^{1,28}$ In the case of an $\mathrm{HP} \beta \mathrm{CD}$ aqueous solution containing $20 \%(\mathrm{w} / \mathrm{w})$ urea, no fibers were yielded, only beads (Figure $2 \mathrm{~g}$ ), because the breakup of the electrospinning jet occurred, which was possibly due to the absence of a sufficient number of $\mathrm{HP} \beta \mathrm{CD}$ aggregates and the low viscosity of the solution. These results showed that the success of the electrospinning of $\mathrm{HP} \beta \mathrm{CD}$ nanofibers without the need of any

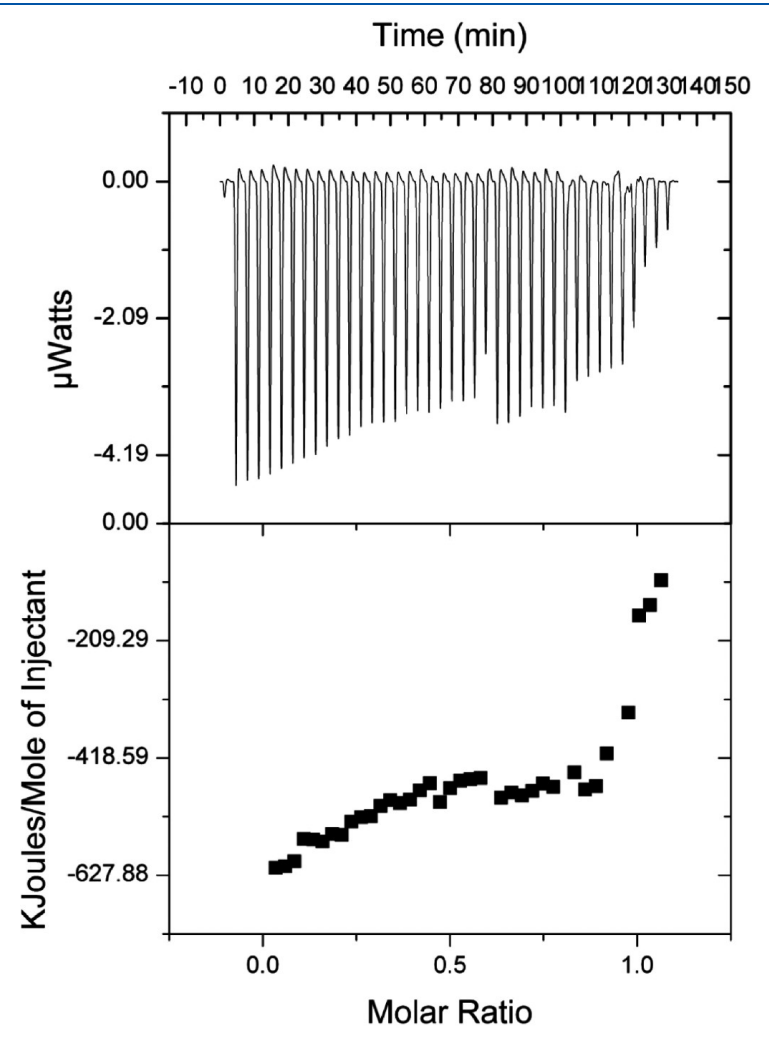

Figure 5. Isothermal calorimetric titration of triclosan with $\mathrm{HP} \beta \mathrm{CD}$ in water at $25^{\circ} \mathrm{C}$ : (upper) raw data for 40 injections of $\mathrm{HP} \beta \mathrm{CD}$ solution into triclosan solution; (lower) titration curve obtained from the integration of the calorimetric traces. polymeric carrier is due to the presence of a considerable number of aggregates and reasonable intermolecular interactions between the $\mathrm{HP} \beta \mathrm{CD}$ molecules in their concentrated solutions.

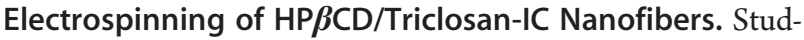
ies have shown that triclosan can form inclusion complexes with different types of cyclodextrins including $\beta-\mathrm{CD},{ }^{31,32} \mathrm{HP} \beta \mathrm{CD},{ }^{33}$ and $\mathrm{M} \beta \mathrm{CD} .{ }^{33}$ Here, we have studied the inclusion complexation of triclosan with $\mathrm{HP} \beta \mathrm{CD}$ by using ITC. ITC is a powerful and highly sensitive technique for studying the interactions between the guest molecules and the host molecules in the CD-IC systems. $^{34,35}$ ITC measurements give thermodynamic and kinetic information as well as the molar stoichiometry of the CDICs. The ITC analyses (Figure 5, Table 3) indicated that the standard formation enthalpy $\left(\Delta H^{\circ}\right)$ of the inclusion complexion between $\mathrm{HP} \beta \mathrm{CD}$ and triclosan was $-521 \pm 9 \mathrm{~kJ} \mathrm{~mol}^{-1}$, signifying that the complex formation is an exothermic processes. In addition, the negative nature of enthalpy changes indicated that the inclusion complexation process is enthalpy-driven. ${ }^{34}$ The entropy effect $(T \Delta S)$ was also negative, so the complexation between $\mathrm{HP} \beta \mathrm{CD}$ and triclosan is entropically unfavorable. ${ }^{34}$ The high value of the association constant $\left(K_{\mathrm{s}}=(9.6 \pm 4.2) \times 10^{6}\right.$ $\mathrm{M}^{-1}$ ) suggested strong host-guest interactions. Moreover, the stoichiometry of the complexation between $\mathrm{HP} \beta \mathrm{CD}$ and triclosan was calculated to be $\sim 1: 1 \mathrm{~mol} / \mathrm{mol}$ from the ITC data $(N=0.98)$.

The inclusion complexation of triclosan with highly concentrated $\operatorname{HP} \beta C D(160 \%, \mathrm{w} / \mathrm{v})$ was also studied visually and by
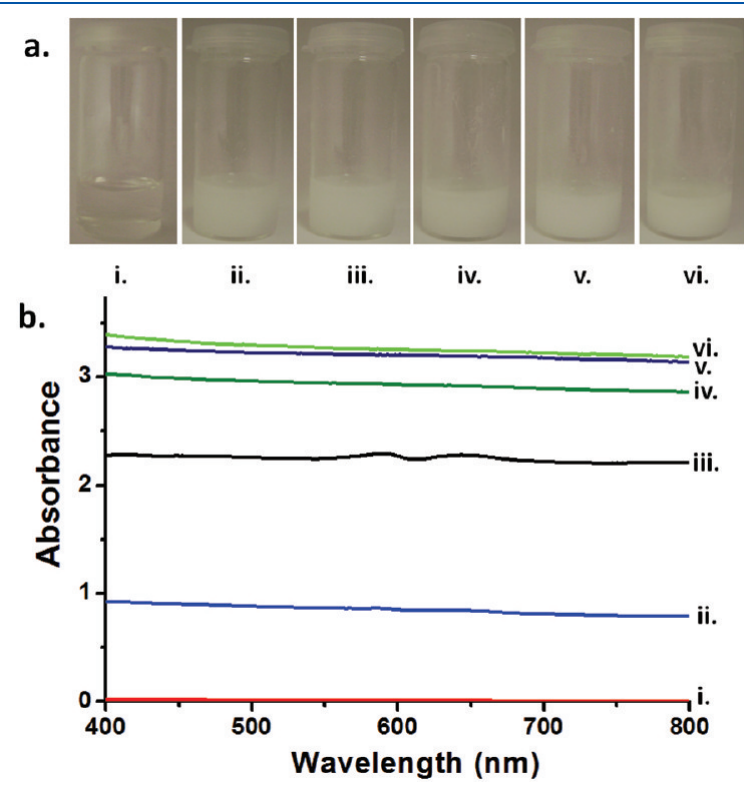

Figure 6. (a) Visual observation of a $\mathrm{H} \beta \mathrm{CD} /$ triclosan-IC (1:1 molar ratio) solution after mixing of the two components for (i) 1 , (ii) 3, (iii) 6, (iv) 9 , (v) 12 , and (vi) $15 \mathrm{~h}$. (b) UV-vis spectrum of the same $\mathrm{H} \beta \mathrm{CD} /$ triclosan (1:1 molar ratio) solution after (i) 1, (ii) 3, (iii) 6, (iv) 9, (v) 12, and (vi) $15 \mathrm{~h}$.

Table 3. Thermodynamic Parameters Obtained from ITC Measurements ${ }^{a}$

$\begin{array}{lcccc}\text { triclosan }(\mathrm{mM}) & \mathrm{HP} \beta \mathrm{CD}(\mathrm{mM}) & N & K_{\mathrm{s}}\left(\mathrm{M}^{-1}\right) \times 10^{6} & \Delta H^{\mathrm{o}}(\mathrm{kJ} / \mathrm{mol}) \\ 0.025 & 0.25 & 0.98 & 9.6 \pm 4.2 & -521 \pm 9 \\ { }^{a} \text { Stoichiometry }(N) \text {, complex stability constants }\left(K_{\mathrm{s}} / \mathrm{M}^{-1}\right) \text {, standard enthalpy changes }\left(\Delta H^{\mathrm{o}} / \mathrm{kJ} \mathrm{mol}^{-1}\right) \text {, and entropy changes }\left(T \Delta S^{\mathrm{o}} / \mathrm{kJ} \mathrm{mol}{ }^{-1}\right) \text { for } \\ \text { inclusion complexation of the triclosan with } \mathrm{HP} \beta \mathrm{CD} \text { in water at } 298 \mathrm{~K} \text {. }\end{array}$



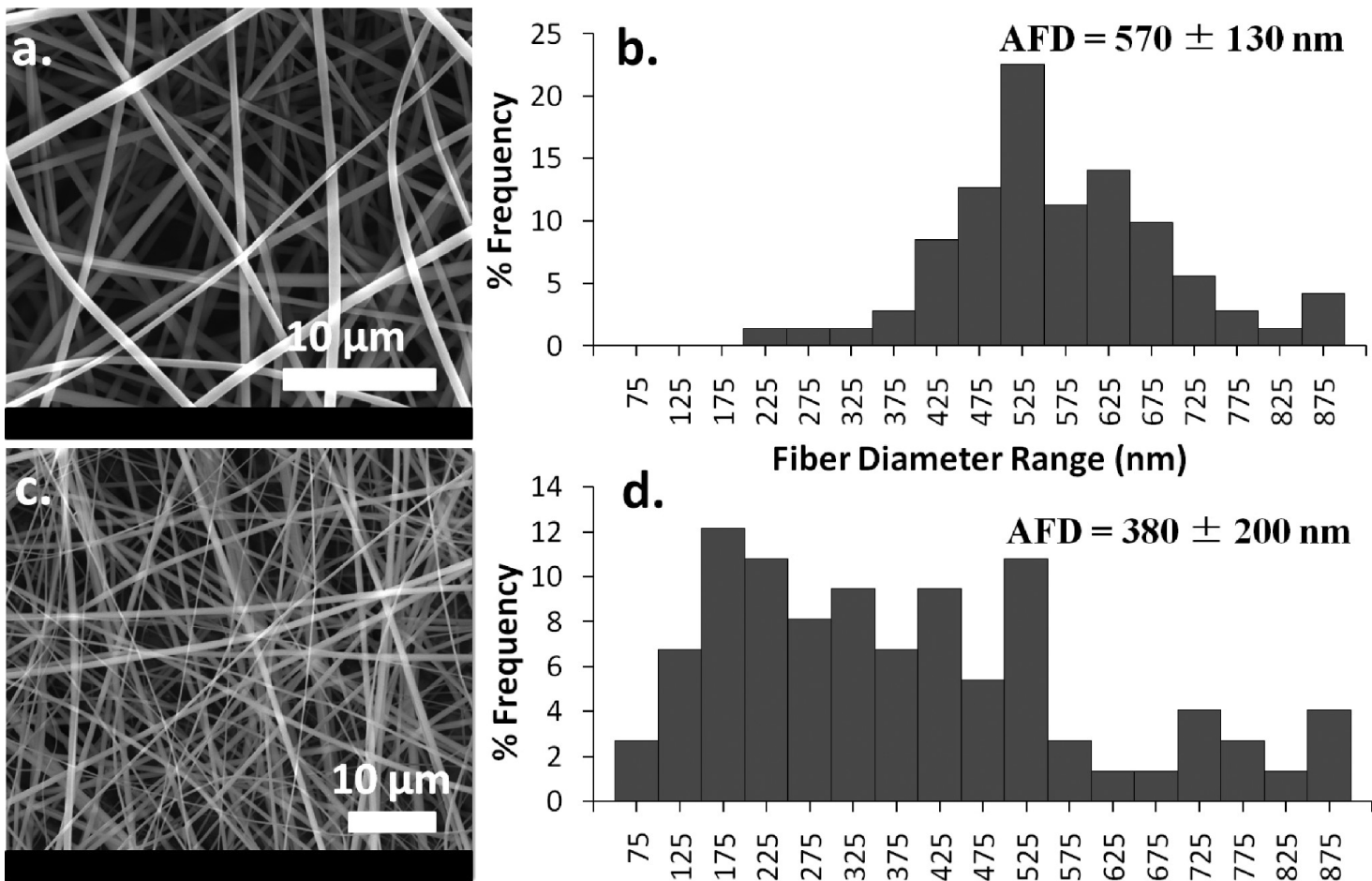

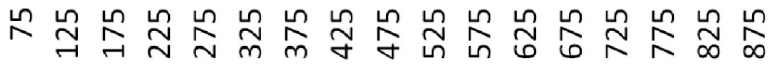
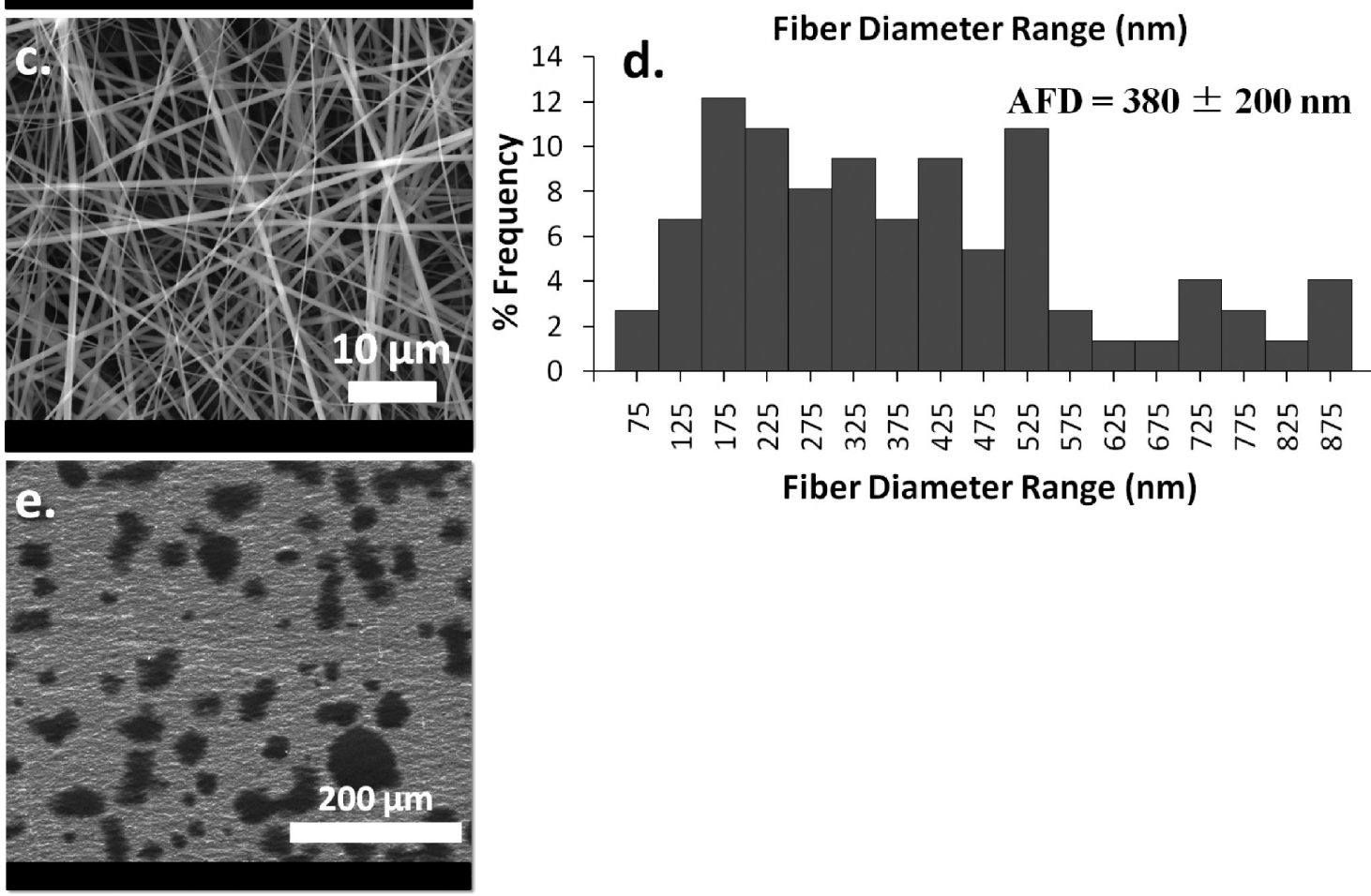

Fiber Diameter Range ( $\mathrm{nm}$ )

Figure 7. Representative SEM images and fiber diameter distribution of the electrospun nanofibers obtained from (a, b) a $160 \%(\mathrm{w} / \mathrm{v}) \mathrm{HP} \beta \mathrm{CD} /$ triclosan-IC (1:1) solution and (c, d) a 160\% (w/v) HP $\beta \mathrm{CD} /$ triclosan-IC (1:1.3) solution, respectively. (e) SEM image of the splashed area obtained from a $160 \%(\mathrm{w} / \mathrm{v}) \mathrm{HP} \beta \mathrm{CD} /$ triclosan-IC (1:1) solution containing $20 \%(\mathrm{w} / \mathrm{w})$ urea.

turbidity measurements performed with a UV-vis spectrometer (Figure 6). Triclosan is insoluble in water and forms a dispersion; however, when $160 \%(\mathrm{w} / \mathrm{v}) \mathrm{HP} \beta \mathrm{CD}$ was added, the solution became clear and transparent because triclosan become watersoluble as a result of the inclusion complexation with $\mathrm{HP} \beta \mathrm{CD}$ (Figure 6a.i). Because the mixing continued for a longer time $(1-15 \mathrm{~h})$, the solution became very turbid because of the aggregation of $\mathrm{HP} \beta \mathrm{CD} /$ triclosan-IC (Figure $6 \mathrm{a}$, ii-vi). Figure $6 \mathrm{~b}$ clearly shows the increasing absorbance values as a function of time for the $\mathrm{HP} \beta \mathrm{CD} /$ triclosan-IC solution as the solution became more turbid. This behavior is typically observed for CD-IC systems as the solubility of CD decreased substantially when complexed with guest molecules and therefore results in very turbid solutions. $33,36,37$

We have prepared $\mathrm{HP} \beta \mathrm{CD} /$ triclosan-IC solutions having two different stoichiometries, that is, $\mathrm{HP} \beta \mathrm{CD} /$ triclosan having a 1:1 molar ratio and one containing a greater number of guest molecules: $\mathrm{HP} \beta \mathrm{CD} /$ triclosan having a 1:1.3 molar ratio. These turbid $\mathrm{HP} \beta \mathrm{CD} /$ triclosan-IC solutions were electrospun into nanofibers by themselves without the addition of any carrier polymeric matrix. The representative SEM images and fiber diameter distributions of the electrospun $\mathrm{HP} \beta \mathrm{CD} /$ triclosan-IC nanofibers are displayed in Figure 7 . Bead-free nanofibers of $\mathrm{HP} \beta \mathrm{CD} /$ triclosan-IC (1:1 molar ratio) (Figure $7 \mathrm{a})$ were obtained with diameters in the range of 200-900 $\mathrm{nm}$ having an average fiber diameter of $570 \pm 130 \mathrm{~nm}$ (Figure $7 \mathrm{~b}$ ). In the case of $\mathrm{HP} \beta \mathrm{CD} /$ triclosan-IC (1:1.3 molar ratio), the bead-free nanofibers (Figure 7c) within the range of 50-900 $\mathrm{nm}$ having an average fiber diameter of $380 \pm 200 \mathrm{~nm}$ were obtained (Figure $7 \mathrm{~d}$ ). The $\mathrm{HP} \beta \mathrm{CD} /$ triclosan-IC nanofibers having a 1:1.3 molar ratio were thinner when compared to those having a 1:1 molar ratio owing to the low solution viscosity (Figure 4a, $\mathrm{v}-\mathrm{vi}$ ) and therefore were subjected to more stretching during electrospinning. Unfortunately, we were not able to perform the DLS measurements because of the turbid nature of the $\mathrm{HP} \beta \mathrm{CD} /$ triclosan-IC solutions; therefore, the size of the aggregates could not be measured. However, the viscosity of the $\mathrm{HP} \beta \mathrm{CD} /$ triclosan-IC solutions was measured to be higher 


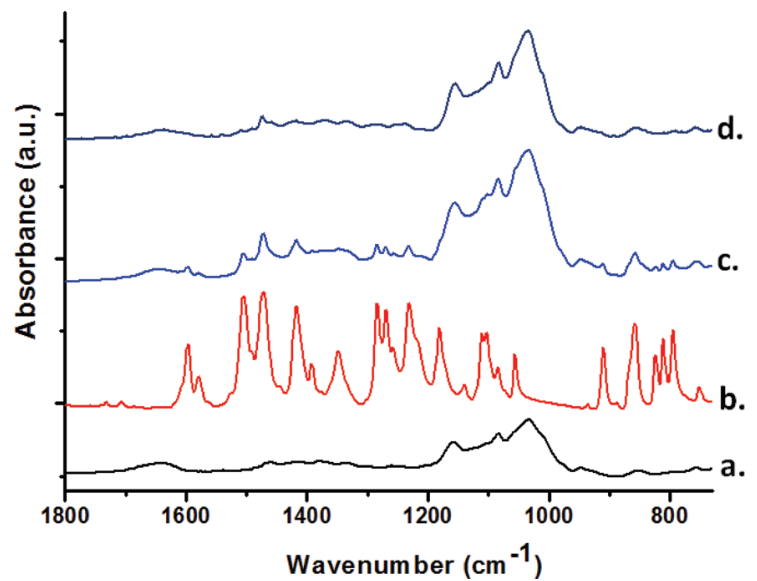

Figure 8. FTIR spectra of (a) $\mathrm{HP} \beta \mathrm{CD}$ nanofibers, (b) pure triclosan, (c) a $\mathrm{HP} \beta \mathrm{CD} /$ triclosan (1:1 molar ratio) physical mixture, and (d) $\mathrm{HP} \beta \mathrm{CD} /$ triclosan-IC (1:1 molar ratio) nanofibers.

than that of the $\mathrm{HP} \beta C D$ solution (Figure 4a, iv-vi), suggesting that a considerable number of aggregates were present in $\mathrm{HP} \beta \mathrm{CD}$ / triclosan-IC solutions and therefore resulted in bead-free nanofibers when electrospun. Similar to $\mathrm{HP} \beta \mathrm{CD}$ solution, the addition of $20 \%(\mathrm{w} / \mathrm{w}$ ) urea to $\mathrm{HP} \beta \mathrm{CD} /$ triclosan-IC lowered the solution viscosity (Figure $4 \mathrm{~b}$, iv) and splashes were obtained instead of fibers (Figure 7e), indicating that the urea disrupted the $\mathrm{HP} \beta \mathrm{CD}$ aggregates and therefore the breakup in the electrospinning jet was inevitable.

Characterization of $\mathrm{HP} \beta C D$ and $\mathrm{HP} \beta \mathrm{CD} /$ Triclosan-IC Nanofibers. The characterizations of the $\operatorname{HP} \beta C D$ and $\operatorname{HP} \beta C D /$ triclosan-IC nanofibers were carried out by FTIR, TGA, XRD, and DSC. Pure triclosan and the physical mixture of $\mathrm{HP} \beta C D$ nanofibers with triclosan were also analyzed for comparison.

The FTIR spectra of pure triclosan, $\mathrm{HP} \beta \mathrm{CD}$ nanofibers, a $\mathrm{HP} \beta \mathrm{CD} /$ triclosan physical mixture, and $\mathrm{HP} \beta \mathrm{CD} /$ triclosan-IC nanofibers are depicted in Figure 8. In the FTIR spectrum of the $\mathrm{HP} \beta \mathrm{CD}$ nanofibers (Figure $8 \mathrm{a}$ ), the salient absorption bands at around 1020 and $1070 \mathrm{~cm}^{-1}$ correspond to the coupled $\mathrm{C}-\mathrm{C}$ and $\mathrm{C}-\mathrm{O}$ stretching vibrations, and the absorption band at around $1150 \mathrm{~cm}^{-1}$ is attributed to the antisymmetric stretching vibration of the $\mathrm{C}-\mathrm{O}-\mathrm{C}$ glycosidic bridge. The FTIR spectrum of pure triclosan (Figure $8 \mathrm{~b}$ ) exhibited characteristic peaks at $1598,1579,1507,1471,1417$, and $1392 \mathrm{~cm}^{-1}$ corresponding to vibrations involving $\mathrm{C}-\mathrm{C}$ stretching inside the benzene ring. ${ }^{32}$ The peaks in the region from 1300 to 1000 and 900 to $750 \mathrm{~cm}^{-1}$ are due to in-plane and out-of-plane bending of the aromatic ring $\mathrm{C}-\mathrm{H}$ bonds, respectively. ${ }^{32}$ For the $\mathrm{HP} \beta \mathrm{CD} /$ triclosan physical mixture, the characteristic peaks for both $\mathrm{HP} \beta \mathrm{CD}$ and triclosan were present without any shifts in the absorption bands (Figure 8c). However, in the case of $\mathrm{HP} \beta \mathrm{CD} /$ triclosan-IC nanofibers, characteristic bands of triclosan such as those at 1471 and $1417 \mathrm{~cm}^{-1}$ shifted to 1474 and $1420 \mathrm{~cm}^{-1}$, respectively (Figure 8d), suggesting the host-guest interactions between $\mathrm{HP} \beta \mathrm{CD}$ and triclosan in the electrospun nanofibers. Similar peak shifts were also reported in the literature for $\mathrm{CD} /$ triclosan inclusion complexes. ${ }^{38}$ In addition, the characteristic peaks of triclosan were suppressed in $\mathrm{HP} \beta \mathrm{CD} /$ triclosan-IC nanofibers when compared to those of its physical mixture. The attenuation of the absorption bands of guest molecules are typically observed for the CD-IC systems because the inclusion of guest molecules in the $\mathrm{CD}$ cavity hinder their molecular vibrations; therefore, the

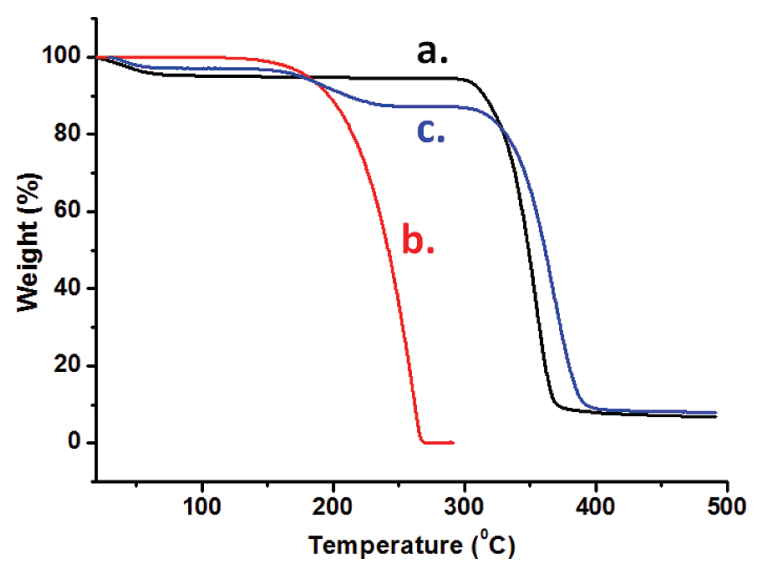

Figure 9. TGA thermograms of (a) $\mathrm{HP} \beta \mathrm{CD}$ nanofibers, (b) pure triclosan, and (c) $\mathrm{HP} \beta \mathrm{CD} /$ triclosan-IC nanofibers (1:1 molar ratio).

intensity of their absorption bands is diminished. ${ }^{38,39}$ In brief, the shifts in the characteristic bands of triclosan and their attenuation suggested strong host-guest interactions in $\mathrm{HP} \beta \mathrm{CD}$ /triclosanIC nanofibers.

TGA thermograms of pure triclosan, $\mathrm{HP} \beta \mathrm{CD}$ nanofibers, and $\mathrm{HP} \beta \mathrm{CD} /$ triclosan-IC nanofibers are given in Figure 9. The TGA curve of $\operatorname{HP} \beta C D$ nanofibers showed two weight losses: the initial weight loss below $100{ }^{\circ} \mathrm{C}$ was due to water loss, and the major weight loss above $300{ }^{\circ} \mathrm{C}$ corresponded to the main thermal degradation of $\mathrm{HP} \beta \mathrm{CD}$ (Figure 9a). In the case of $\mathrm{HP} \beta \mathrm{CD} /$ triclosan-IC nanofibers, three weight losses were observed: the water loss below $100{ }^{\circ} \mathrm{C}$, the second weight loss between 150 and $250{ }^{\circ} \mathrm{C}$ that was due to the evaporation/ degradation of triclosan, and the main degradation of $\mathrm{HP} \beta \mathrm{CD}$ above $300{ }^{\circ} \mathrm{C}$ (Figure 9c). From the TGA data, the amount of triclosan was calculated to be $\sim 10 \%(\mathrm{w} / \mathrm{w}$, with respect to $\mathrm{HP} \beta \mathrm{CD}$ ) in the $\mathrm{HP} \beta \mathrm{CD} /$ triclosan-IC nanofibers that correspond to 1:1 molar ratio complexation between $\mathrm{HP} \beta \mathrm{CD}$ and triclosan. The TGA data correlates with the ITC data, and 1:1 complexation between $\mathrm{HP} \beta \mathrm{CD}$ and triclosan was obtained from ITC measurements. The TGA findings also indicate that the initial amount of triclosan was preserved and no loss of guest molecules has occurred during the electrospinning process. The preservation of triclosan during electrospinning is also evidence of its complexation with $\mathrm{HP} \beta \mathrm{CD}$ because its stability was sustained against evaporation. For instance, we previously observed that an additive such as menthol without a CD complex could not be preserved during the electrospinning process of the polystyrene/menthol mixture. ${ }^{24}$ In the case of complexation, the water molecules inside the $\mathrm{CD}$ cavity are displaced by the guest molecules. In addition, the temperature stability of a volatile guest molecule would increase because of the interaction with the $\mathrm{CD}$ cavity. ${ }^{39-41} \mathrm{HP} \beta \mathrm{CD} /$ triclosan-IC nanofibers have minimal water content when compared to $\mathrm{HP} \beta \mathrm{CD}$ nanofibers. Moreover, TGA of $\mathrm{HP} \beta \mathrm{CD} /$ triclosan-IC nanofibers showed that the thermal degradation temperature $\left(T_{\mathrm{d}}\right)$ of triclosan has slightly shifted to higher temperature $\left(T_{\mathrm{d}}\right.$ onset at $\left.\sim 150^{\circ} \mathrm{C}\right)$ when compared to that of pure triclosan $\left(T_{\mathrm{d}}\right.$ onset at $\left.\sim 140^{\circ} \mathrm{C}\right)$. In short, the TGA findings suggested that triclosan was in the complexed state with $\mathrm{HP} \beta \mathrm{CD}$ in the nanofibers.

The XRD patterns of the $\mathrm{HP} \beta \mathrm{CD}$ /triclosan-IC nanofibers are very similar to those of pure $\mathrm{HP} \beta \mathrm{CD}$ nanofibers having amorphous structures (Figure 10). In the CD-ICs, the guest molecules 


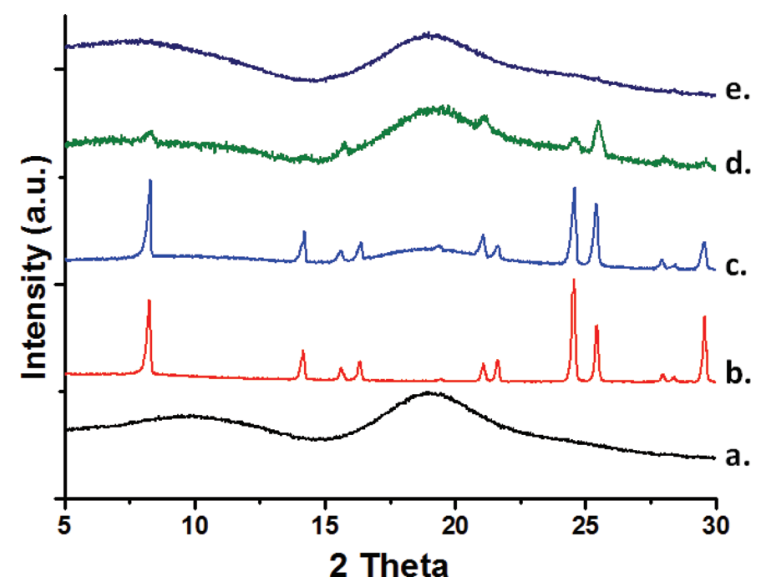

Figure 10. XRD patterns of (a) $\mathrm{HP} \beta \mathrm{CD}$ nanofibers, (b) pure triclosan, (c) $\mathrm{H} \beta \mathrm{CD} /$ triclosan (1:1 molar ratio) physical mixture, (d) $\mathrm{HP} \beta \mathrm{CD} /$ triclosan-IC nanofibers (1:1.3 molar ratio), and (e) $\mathrm{HP} \beta \mathrm{CD} /$ triclosanIC nanofibers (1:1 molar ratio).

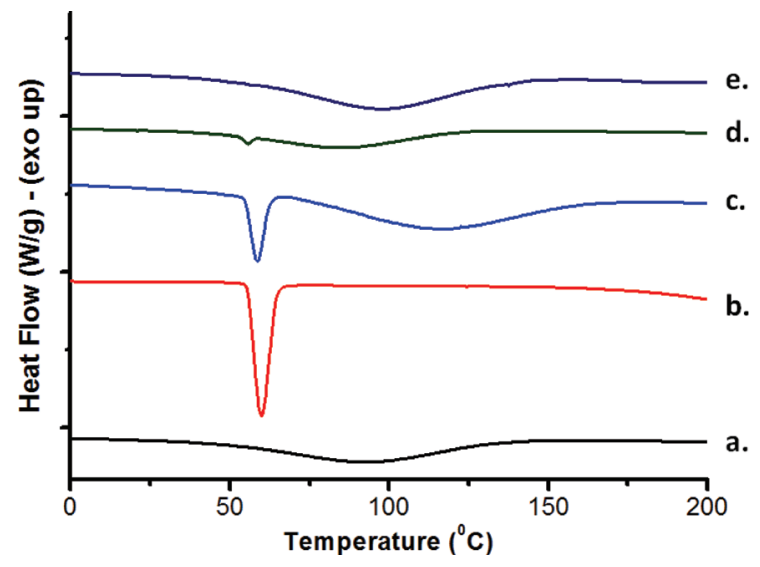

Figure 11. DSC thermograms of (a) $\operatorname{HP} \beta C D$ nanofibers, (b) pure triclosan, (c) a $\mathrm{H} \beta \mathrm{CD} /$ triclosan (1:1 molar ratio) physical mixture, (d) a $\mathrm{HP} \beta \mathrm{CD} /$ triclosan-IC nanofibers (1:1.3 molar ratio), and (e) $\mathrm{HP} \beta \mathrm{CD} /$ triclosan-IC nanofibers (1:1 molar ratio).

are isolated from each other by the $\mathrm{CD}$ cavities; therefore, they cannot form crystals. ${ }^{40}$ The XRD of $\mathrm{HP} \beta \mathrm{CD} /$ triclosan-IC nanofibers (Figure 10e) has shown no diffraction pattern for triclosan, suggesting that the triclosan molecules were included inside the $\mathrm{HP} \beta \mathrm{CD}$ cavity. However, the physical mixture of $\mathrm{HP} \beta \mathrm{CD} /$ triclosan has diffraction peaks for uncomplexed triclosan (Figure 10c).

DSC is a useful technique for determine whether the guest molecules are included inside the CD cavities. ${ }^{39,40}$ A thermal transition such as the melting point $\left(T_{\mathrm{m}}\right)$ for guest molecules would be observed if there are any free uncomplexed guest molecules present in the CD-IC system. DSC scans of pure triclosan (Figure 11b) and the physical mixture of $\mathrm{HP} \beta \mathrm{CD} /$ triclosan (Figure 11c) exhibited a melting point for triclosan at around $60{ }^{\circ} \mathrm{C}$ whereas no melting point was observed for the $\mathrm{HP} \beta \mathrm{CD} /$ triclosan-IC (1:1) nanofibers (Figure 11e), suggesting that the triclosan molecules were included inside the $\mathrm{HP} \beta \mathrm{CD}$ cavity. In short, the absence of a thermal event such as $T_{\mathrm{m}}$ for guest molecules in $\mathrm{HP} \beta \mathrm{CD} /$ triclosan-IC nanofibers is evidence of true inclusion complexation.
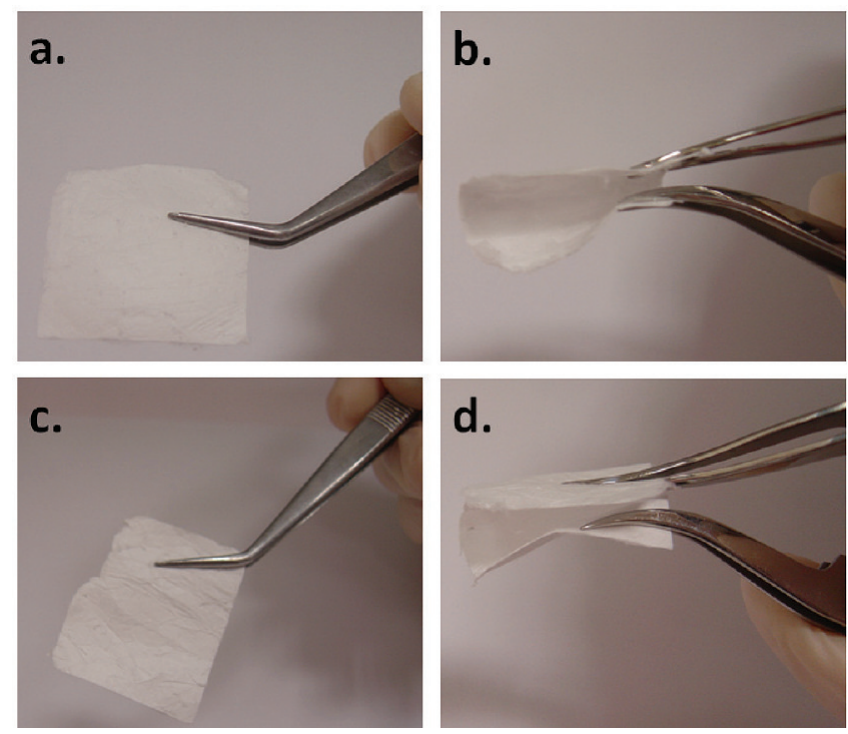

Figure 12. Photographs showing that the nanofibrous webs have mechanical integrity and can be easily handled and folded as a free-standing web. (a, b) HP $\beta$ CD nanoweb. (c, d) $\mathrm{HP} \beta \mathrm{CD}$ /triclosan-IC (1:1 molar ratio) nanoweb.

The XRD of $\mathrm{HP} \beta \mathrm{CD} /$ triclosan-IC (1:1.3 molar ratio) nanofibers has shown diffraction peaks (Figure 10d), and the DSC scan exhibited a melting point at around $60^{\circ} \mathrm{C}$ (Figure 11d) that is due to the presence of some uncomplexed triclosan molecules. These findings suggest that the electrospinning of nanofibers from $\mathrm{HP} \beta \mathrm{CD} /$ triclosan-IC having a 1:1 molar ratio is optimal for obtaining $\mathrm{HP} \beta \mathrm{CD}$-IC nanofibers without any free guest molecules. ${ }^{31,42}$ This also correlates with ITC and TGA findings as discussed previously.

The mechanical integrity of $\mathrm{HP} \beta \mathrm{CD}$ and $\mathrm{HP} \beta \mathrm{CD} /$ triclosanIC nanofibrous webs was tested qualitatively. Compared to electrospun polymeric nanowebs, they were expected to be weak because they are made of amorphous small molecules. Nevertheless, our observations indicated that these $\mathrm{HP} \beta \mathrm{CD}$ and $\mathrm{HP} \beta \mathrm{CD} /$ triclosan-IC nanofibrous webs have some mechanical integrity and they can be easily handled and folded as a freestanding web (Figure 12).

\section{CONCLUSIONS}

The electrospinning of nanofibers from CD-IC is quite challenging because it is a nonpolymeric system. At the same time, electrospun CD-IC nanofibers would be very intriguing because of the exclusive properties obtained by the very large surface area of the nanofibers along with specific functionalities of CD-IC supramolecular structures. In this study, we report the first results on the electrospinning of nanofibers from CD-IC without the use of any polymeric carrier. A widely used antibacterial agent (triclosan) was complexed with $\mathrm{HP} \beta \mathrm{CD}$ and then electrospun into uniform nanofibers. DLS and rheology measurements elucidated that bead-free nanofibers of $\mathrm{HP} \beta \mathrm{CD}$ and $\mathrm{HP} \beta \mathrm{CD} /$ triclosan-IC were able to be electrospun because of the presence of sufficient aggregates and intermolecular interactions between the $\mathrm{HP} \beta \mathrm{CD}$ molecules in their highly concentrated $(160 \%, \mathrm{w} / \mathrm{v})$ aqueous solutions. The addition of $20 \%(\mathrm{w} / \mathrm{w})$ urea to $\mathrm{HP} \beta \mathrm{CD}$ and $\mathrm{HP} \beta \mathrm{CD} /$ triclosan-IC solutions resulted in the depression of the self-aggregation of the $\mathrm{HP} \beta \mathrm{CD}$ molecules; 
therefore, these solutions yielded no fibers but only beads and splashes when electrospun. The FTIR, TGA, XRD, and DSC analyses suggested the presence of a host-guest interaction between triclosan and $\mathrm{HP} \beta \mathrm{CD}$ in the electrospun nanofibers. It was found that having 1:1 host-guest complexation was optimal for $\mathrm{HP} \beta \mathrm{CD} /$ triclosan-IC nanofibers without any free guest molecules. We are currently investigating the stability, release profile, and antibacterial properties of $\mathrm{HP} \beta \mathrm{CD} /$ triclosan-IC nanofibers.

\section{AUTHOR INFORMATION}

\section{Corresponding Author}

*E-mail: tamer@unam.bilkent.edu.tr. Phone: (+90)3122903571. Fax: $(+90) 3122664365$.

\section{ACKNOWLEDGMENT}

The State Planning Organization (DPT) of Turkey is acknowledged for the support of UNAM-Institute of Materials Science \& Nanotechnology. T.U. acknowledges EU FP7-PEOPLE-2009-RG Marie Curie-IRG for funding the NANOWEB (PIRG06-GA-2009-256428) project. A.C. acknowledges TUBITAK-BIDEB for the national graduate study scholarship.

\section{REFERENCES}

(1) Ramakrishna, S.; Fujihara, K.; Teo, W.; Lim, T.; Ma, Z. An Introduction to Electrospinning and Nanofibers; World Scientific Publishing Company: Singapore, 2005.

(2) Li, D.; Xia, Y. Adv. Mater. 2004, 16, 1151.

(3) Ramakrishna, S.; Fujihara, K.; Teo, W. E.; Yong, T.; Ma, Z.; Ramaseshan, R. Mater. Today 2006, 9, 40.

(4) Greiner, A.; Wendorff, J. Angew.Chem., Int. Ed. 2007, 46, 5670.

(5) Kriegel, C.; Kit, K. M.; McClements, D. J.; Weiss, J. Langmuir 2009, $25,1154$.

(6) Lim, H. S.; Park, S. H.; Koo, S. H.; Kwark, Y. J.; Thomas, E. L.; Jeong, Y.; Cho, J. H. Langmuir 2010, 26, 19159.

(7) Wang, C.; Hsu, C.-H.; Lin, J.-H. Macromolecules 2006, 39, 7662.

(8) Shenoy, S.; Bates, W.; Frisch, H.; Wnek, G. Polymer 2005, 46, 3372.

(9) Cashion, M. P.; Li, X.; Geng, Y.; Hunley, M. T.; Long, T. E. Langmuir 2010, 26, 678.

(10) McKee, M.; Layman, J.; Cashion, M.; Long, T. Science 2006, 311, 353.

(11) Celebioglu, A.; Uyar, T. Chem. Commun. 2010, 46, 6903.

(12) Szente, L.; Szejtli, J.; Kis, G. J. Pharm. Sci. 1998, 87, 778.

(13) Bonini, M.; Rossi, S.; Karlsson, G.; Almgren, M.; Nostro, L. P.; Baglioni, P. Langmuir 2006, 22, 1478.

(14) Messner, M.; Kurkov, S.; Jansook, P.; Loftsson, T. Int. J. Pharm. 2009, 387, 199.

(15) Hedges, A. R. Chem. Rev. 1998, 98, 2035.

(16) Szejtli, J. Chem. Rev. 1998, 98, 1743.

(17) Samperio, C.; Boyer, R.; Eigel, W. N.; Holland, K. W.; McKinney, J. S.; O'Keefe, S. F.; Smith, R.; Marcy, J. E. J. Agric. Food Chem. 2010, 58,12950

(18) Xu, M.; Wu, S.; Zeng, F.; Yu, C. Langmuir 2010, 26, 4529.

(19) Park, I. K.; von Recum, H. A.; Jiang, S.; Pun, S. H. Langmuir 2006, 22, 8478.

(20) Uyar, T.; Havelund, R; Hacaloglu, J.; Besenbacher, F.; Kingshott, P. ACS Nano 2010, 4, 5121.

(21) Uyar, T.; Havelund, R.; Hacaloglu, J.; Zhou, X.; Besenbacher, F.; Kingshott, P. Nanotechnology 2009, 20, 125605.

(22) Uyar, T.; Balan, A.; Toppare, L.; Besenbacher, F. Polymer 2009, 50,475 .

(23) Uyar, T.; Nur, Y.; Hacaloglu, J.; Besenbacher, F. Nanotechnology 2009, 20, 125703.
(24) Uyar, T.; Hacaloglu, J.; Besenbacher, F. React. Funct. Polym. 2009, 69, 145.

(25) Uyar, T.; Kingshott, P.; Besenbacher, F. Angew. Chem., Int. Ed. 2008, 47, 9108.

(26) Coleman, A. W.; Nicolis, I.; Keller, N.; Dalbiez, J. P. J. Inclusion Phenom. Macrocyclic Chem. 1992, 13, 139.

(27) Hausler, O.; Muller-Goymann, C. C. Starch/Staerke 1993, 45, 183.

(28) Uyar, T.; Besenbacher, F. Polymer 2008, 49, 5336.

(29) Hinze, W.; Pharr, D. Y.; Fu, Z. S.; Burkert, W. G. Anal. Chem. $1989,61,422$

(30) González-Gaitano, G.; Rodríguez, P.; Isasi, J. R.; Fuentes, M.; Tardajos, G.; Sánchez, M. J. Inclusion Phenom. Macrocyclic Chem. 2002, 44, 101.

(31) Paulidou, A.; Maffeo, D.; Yannakopoulou, K.; Mavridis, I. M. Carbohyd. Res. 2008, 343, 2634.

(32) Jug, M.; Kosalec, I.; Maestrelli, F.; Mura, P. J. Pharm. Biomed. 2011, 54, 1030.

(33) Duan, M. S.; Zhao, N.; Ossurardottir, I. B.; Thorsteinsson, T.; Loftsson, T. Int. J. Pharm. 2005, 297, 213.

(34) Qiu, X. M.; Sun, D. Z.; Wei, X. L.; Yin, B. L. J. Solution Chem. 2007, 36, 303.

(35) Othman, M.; Bouchemal, K.; Couvreur, P.; Gref, R. Int. J. Pharm. 2009, 379, 218.

(36) Harada, A.; Li, J.; Kamachi, M. Macromolecules 1993, 26, 5698.

(37) Becheri, A.; Nostro, P. L.; Ninham, B. W.; Baglioni, P. J. Phys. Chem. B 2003, 107, 3979.

(38) Guan, Y.; Qian, L.; Xiao, H. Macromol. Rapid Commun. 2007, $28,2244$.

(39) Koontz, J. L.; Marcy, J. E.; O'keefe, S. F.; Duncan, S. E. J. Agric. Food Chem. 2009, 57, 1162.

(40) Giordano, F.; Novak, C.; Moyano, J. R. Thermochim. Acta 2001, $380,123$.

(41) Uyar, T.; Hunt, M. A.; Gracz, H. S.; Tonelli, A. E. Cryst. Growth Des. 2006, 6, 1113.

(42) Sigurdsson, H. H.; Knudsen, E.; Loftsson, T.; Leeves, N.; Sigurjonsdottir, J. F.; Másson, M. J. Inclusion Phenom. Macrocyclic Chem. 2002, 44, 169. 